\title{
Poznámky k dvojdomosti české \\ fantastické literatury po roce 1989
}

\author{
Jan Křeček
}

\section{ABSTRACT \\ On Dioecy of the Czech Fantastic Literature after 1989}

The paper deals with the problem of dioecy in the Czech fantastic literature. There are two spheres of fantastic literature - the first is the popular one, associated with fandom, publishing houses, and specialized bookshops, the second one can be classified as "high literature" and is usually mimetic, therefore the reader may not expect any fantastic elements in it. However, there are fantastic elements present here - and often enough. One sphere usually does not accept the second one, though, as shown on examples of short stories by Jan Dobiáš and a novella by René Vaněk. The extratextual features are only one way to look at fantastic literature. Another possibility is to study the use of the fantastic element. And as presented here, the intratextual analysis divides fantastic literature at a completely different level than the extratextual analysis.

\section{KEYWORDS}

Czech fantastic literature; Tereza Dědinová; Po divné krajině; Jan Dobiáš; Po dračím ohni; Neočekávané dýchánky; René Vaněk; Soma secundarium; fantastic element; fuzzy sets; the pure fantastic; fantastic as a mean of expression; popular fantastic; Antonín K. K. Kudláč; Anatomie pocitu úžasu; Barvy černobilého světa.

\section{KLÍčOVÁ SLOVA}

Česká fantastická literatura; Tereza Dědinová; Po divné krajině; Jan Dobiáš; Po dračím ohni; Neočekávané dýchánky; René Vaněk; Soma secundarium; fantastický prvek; neostré množiny; vlastní fantastično; fantastično jako prostředek vyjádření; populární fantastika; Antonín K. K. Kudláč; Anatomie pocitu úžasu; Barvy černobilého světa. 


\section{1 Úvod}

Jedním ze základních problémů české fantastické literatury je její dvojdomost. Na jedné straně existují fandom ${ }^{1}$ a s ním spojená žánrová nakladatelství, knihkupectví a média, na druhé straně vznikají díla s fantastickým prvkem, která s komunitou fanoušků nijak nesouvisejí. Je možné nabídnout přinejmenším dvojí vysvětlení tohoto jevu: bud’ jde o rozdělení pouze na základě extratextuálních znaků (příslušnost ke komunitě, nakladatelství, ve kterém titul vyjde, a podobně), a jde tedy o vnější, vnitřně nekonzistentní faktor, nebo existují objektivní textová kritéria, pro která je literatura s fantastickým prvkem dvojdomá. Tato studie shrnuje dosavadní zkoumání a stav dvou prezentovaných množin a následně se věnuje extratextuálnímu a intratextuálnímu rozboru, tedy ukazuje, že dochází ke zkreslení při hodnocení na základě zařazení do jedné $\mathrm{z}$ daných množin, respektive k prolínání textů mezi oběma množinami bez ohledu na předchozí příslušnost $\mathrm{k}$ jedné či druhé. Na základě omezeného textového vzorku nelze dělat všeobecné závěry, nicméně naznačit řešení možné je.

Vedle problému dvojdomosti existuje problém toho, co vưbec je fantastická literatura. Problematika žánru, toho, že mnozí autoři (v českém kontextu Šidák, Dědinová, ve světovém Attebery) pojímají fantastiku spíše jako modus (více např́klad ŠIDÁK 2013: 90-92), by vydala na samostatnou studii. Zde bude dostačující přihlášení se k první kategorii ze tř́í, které navrhuje Pavel Šidák v Úvodu do studia genologie: „V nejobecnějším významu je fantastika totožná s oblastí ne-realismu (s vědomím, že sám pojem „realismu“ je pohyblivý). Pak představuje širokou oblast nejrůznějších žánrů, v nichž fantastický prvek slouží různým funkcím“ (ŠIDÁK 2013: 249-250).

Na fantastický prvek a jeho funkci se dále zaměřuje Tereza Dědinová. Ta upozorňuje na existenci dvou neostrých množin fantastické literatury v monografii Po divné krajině (2015): zjednodušíme-li její závěry, vlastní fantastično je množina textů, které „se primárně soustředí na fantastický prvek, na jeho věrohodné zasazení do kontextu fikčního světa a domyšlení důsledků, které s sebou fantastický prvek nese“; kromě toho je pro takováto díla důležité „přihlášení se autora ke směru, úspěšně zařazení do komunity a tvorba v jejích intencích (...) publikování v komunitních periodikách a nakladatelstvích (popřípadě edicích), účast na komunitních setkáních (conech) a podobně“. Druhá neostrá množina, fantastično jako prostředek vyjádření, označuje texty, které využívají fantastický

1) K definici fandomu např. MACEK 2006: 13-45 nebo KUDLÁČ 2016: 95-117. 
prvek, ale „nejsou propojeny komunitou tvůrců a recipientů tak, jak je tomu v případě vlastního fantastična“ (všechny citace DĚDINOVÁ 2015: 105-108).

Obě množiny jsou od počátku dány jako neostré - vzájemně se prostupující. Tereza Dědinová proto používá termín literární fantastika, kterým označuje „fantastická díla nezávisející na striktních předpokladech fantastiky staršího ražení (fantastika jako popularizátor vědy a techniky a podobně) a mířící mimo hranice triviální literatury - je psána autory s komunitou spjatými a obeznámenými s kánonem, $\mathrm{v}$ jejich textech ale důsledně promyšlený fantastický prvek nabývá vícera funkcí“ (DĚDINOVÁ 2015: 107).

Podíváme-li se na obě neostré množiny a jejich vývoj od roku 1989 do současnosti blíže, zjistíme, že prostupnost je oboustranná a že vzájemné vztahy spíše expandují.

\section{Vlastní fantastično $\mathrm{v}$ české fantastické literatuře po roce 1989}

\subsection{VNITŘNí ROZDĚLENÍ MNOŽINY VLASTNÍHO FANTASTIČNA}

Tereza Dědinová definuje vlastní fantastično ze dvou hledisek: za prvé fantastický prvek a jeho funkce $v$ textu, za druhé intence autora být zařazen do fantastiky. Bez hlubšího zkoumání funkce fantastického prvku lze dospět k názoru, že k určení toho, co je a co není fantastická literatura, by mohly stačit extratextuální znaky. K posouzení věrohodného zasazení fantastického prvku do kontextu fikčního světa je třeba analýzy textu, pokusme se tedy zatím definovat druhé hledisko - přihlášení se ke směru, zařazení do komunity, tvorba v intencích komunity.

Do roku 2017 včetně byly vydány čtyři monografie, které se zabývají „populární fantastikou“ („populární ${ }^{2}$ fantastiku“ jako intermediální fenomén prosazuje A. K. K. Kudláč3 ): Něco je jinak Ondřeje Neffa (1981) a Průvodce paralelními světy.

2) V této studii bude použit i výraz „žánrový“ (např. „žánrová nakladatelství“ a podobně), který lze v kontextu považovat za synonymní. Tereza Dědinová použivá pojem „triviální literatura“, v níž „dobrodružný př́iběh ve fantastických kulisách často deklaruje svou př́íslušnost $\mathrm{k}$ fantastice přihlášením se k žánru a naplňováním jeho konvencí a klišé“ (DĚDINOVÁ 2015: 82).

3) Termín definuje následovně: „Z hlediska literární genologie tvoří populární literatura specifický subsystém písemnictví, literární fantastika (...) je pak žánrovou oblastí nebo modem literatury jako takové, tedy prochází vlastně napříč všemi jejími subsystémy (populární literatura, „vysoká“ či elitní literatura, folklorní literatura). 
Nástin vývoje české sci-fi 1976-1993 Aleše Langera (2006) hodnotí starší etapy české sci-fi, Anatomie pocitu úžasu Antonína K. K. Kudláče (2016) a Barvy černobílého světa (2017) téhož autora pojednávají o novější éře. Všechny tyto práce se týkají fantastické literatury spojené s fandomem. Začátkům žánrové fantastiky je věnována i kapitola v „akademických“ Dějinách české literatury 1945-1989 (IV. díl). Tam je ostatně odlišnost „vědeckofantastické prózy“, jak je tento druh literatury označen, shrnuta v závěru:

\begin{abstract}
„Představa o splynutí science fiction s elitní národní literaturou se po listopadu 1989 ukázala jako neudržitelná. Politická změna otevřela prostor pro plnou konstituci vlastního, bohatě strukturovaného komunikačního okruhu a SF fandom také této př́ležitosti velmi rychle využil: již v červnu 1990 vyšlo první číslo specializovaného měsíčníku Ikarie. Skutečnost, že se česká vědeckofantastická próza plně integrovala do světa populární kultury, potvrdila i literární kritika spojená s ,velkou literaturou“, která si další sci-fi produkce přestala všímat“" (JANOUŠEK 2008: 717).
\end{abstract}

Tvrzení o nereálnosti splynutí science fiction s elitní národní literaturou potvrzuje i dřivější zkušenost Josefa Nesvadby zaznamenaná Ondřejem Neffem v monografii Něco je jinak: „Když byl (Josef Nesvadba, pozn. JK) v Oaklandu, spisovatelé žili izolováni od literatury ,mainstream' a od běžného literárního života. Měli své publikum, svá nakladatelství, své magazíny, své kritiky. Sarkasticky to nazývali ,ghettem“" (NEFF 1981: 324).

K fantastické literatuře spjaté s komunitou fanoušků tedy nepatří jen pojmosloví převzaté $z$ anglického jazyka a dnes běžně užívané čtenáři (žánrové kategorie science fiction, fantasy, horor; ale i subkategorie jako steampunk, space opera, New Weird a podobně), ale i zcela konkrétní instituce zaměřené na fandomový trh a aktivity fandomem vytvářené. Jsou to zejména nakladatelství, časopisy, webové stránky, knihkupectví a cony.

\title{
2.2 EXTRATEXTUÁLNÍ ZNAKY „POPULÁRNÍ FANTASTIKY“ PO ROCE 1989
}

Existence mnoha žánrových nakladatelství po roce 1989 je spjata jak s nástupem tržně liberálního prostředí, tak s konkrétními sci-fi kluby. Nakladatelství často vznikla institucionalizací klubů, které vydávaly knihy nebo časopisy

Populární fantastiku chápu jako intermediální fenomén zahrnující také tu část fantastiky, která spadá do subsystému populární literatury“ (KUDLÁČ 2016: 13). Nutno dodat, že k definici je připojeno zpřesňující schéma.

4) V roce 1994 vycházely části této disertační práce na pokračování v časopisu Interkom, v roce 2006 pak vyšel přepracovaný text znovu i s dodatky „po deseti letech“. 
(prakticky v samizdatové podobě) i dříve. Tuto skutečnost lze ilustrovat na příbězích nakladatelství, jako jsou Klub Julese Vernea (sci-fi klub od roku 1969, na přelomu 80. a 90. let začal s překlady příběhů o barbaru Conanovi, existuje pod stejným názvem dodnes), Laser (dříve SFK Laser Čelákovice, dnes Laser-books), Winston Smith (původně SFK Winston, od roku 1990 nakladatelství Winston Smith, později Wales) a další.

Druhá vlna geneze žánrových nakladatelství je bez návaznosti na společenské události spojena s rokem 1998 - vznikají Straky na vrbě, Brokilon nebo Viking (původně zaměřeno na vydávání příběhů barbara Conana ${ }^{5}$ ). Zejména Straky na vrbě a Brokilon produkují knihy českých autorů (např. Jan Dobiáš, Leonard Medek, Petra Neomillnerová, Jana Rečková, Pavel Renčín, Vladimír Šlechta a další).

V posledních deseti letech najdeme ryze žánrové edice i u jinak nežánrových nakladatelství - Argo od přelomu tisíciletí vydává dílo P. K. Dicka, postupně se přidaly tituly od Douglase Adamse a v posledních letech i knihy českých a slovenských autorů (Vilma Kadlečková, František Novotný, Josef Karika, Pavel Renčín...), brněnské nakladatelství Host začalo s edicí žánrové fantastické literatury v roce 2013 (autoři jako Pavel Gotthard, Petra Stehlíková, Pavel Bareš).

$\mathrm{Na}$ přelomu 80. a 90. let se etablovalo několik periodik vzešlých z fandomových tiskovin. Nejprofesionálněji působily fanziny Ikarie XB-1 a AF-167 (MACEK 2006: 49). Přestože AF-167 v roce 1992 zaniká, Ikarie XB-1 pokračuje jako časopis Ikarie a posléze jako XB-1 (od roku 2010). Po dalších více či méně úspěšných pokusech o tištěné periodikum (viz např. MACEK 2006) vychází v roce 2002 první číslo časopisu Pevnost, který existuje jako měsíčník dodnes. Tyto dva časopisy (tedy XB-1 a Pevnost) lze v současnosti považovat za jediná profesionální žánrová periodika. Zvláštní postavení má mezi žánrovými časopisy „informační servis českého fandomu“ Interkom, který vychází nepřetržitě od roku 1984.

První žánrová webová stránka FantasyPlanet (http://www.fantasyplanet.cz/) vznikla 4. května 2000 (JIREŠ 2004). Ještě týž měsíc, konkrétně 26. května 2000 (RAMPAS 2000), vznikla rubrika internetového deníku Neviditelný pes s názvem Sarden (http://sarden.cz/). Obě webové stránky existují s určitými obměnami (personálními i vizuálními) dodnes - a jsou postupně doplňovány dalšími. V současnosti jsou funkční a pravidelně aktualizované i webové

5) V letech 1998-2000 vydávalo nakladatelství Viking překlady z angličtiny, od roku 2001 zachovalo jako jedno z mála trend 90. let, a sice vydávat Conanovy příběhy od českých autorů, ovšem pod pseudonymy. Dokonce ještě v roce 2012 vyšly podruhé romány Conan a tajemství mořských d'áblů a Conan a dédictví Atlantidy Otomara Dvořáka pod pseudonymem Paul O. Courtier (původně 2002, respektive 2001). Více o pseudonymech v české fantastické literatuře 90. let KUDLÁČ 2016: 75-76. 
stránky časopisu XB-1 (http://www.casopisxb1.cz/) a dále webové stránky Děti noci (http://deti-noci.cz/), Fantasya (http://fantasya.cz/), MFantasy (https:// www.mfantasy.cz/), Vlčí bouda (http://vlcibouda.net/), z nejnovějších pak FantasyMag (https://www.fantasymag.cz/) a Vanili.cz (www.vanili.cz/scifi/). Situace je ovšem proměnlivá, o čemž svědčí např. situace webzinu s názvem Dagon: 8. dubna 2018 jeho autoři oznámili, že budou po pěti letech aktivního působení pokračovat pouze na sociální síti Facebook a že ukončují činnost jako webzin (DAGON 2018, HARTMAN 2018). Všechna tato média (časopisy i webové stránky) zastávají také roli kritických platforem fandomu - to, čím jsou běžným čtenářům se zájmem o literaturu Host, Tvar, iLiteratura nebo Souvislosti, jsou pro zájemce o fantastickou literaturu výše zmíněná média.

Specializované prodejny knih se obvykle nacházejí ve větších městech - v Praze např. knihkupectví Krakatit, Arkham nebo Fantasya, v Brně Arrakis, v Ostravě Matrix. Často jsou prodejny spojeny s konkrétním nakladatelstvím a velmi často se stálým okruhem zákazníků.

Con ( $\mathrm{z}$ anglického convention, tedy shromáždění, kongres) je označení pro setkání fanoušků fantastické literatury. Nejsou tolik spojeny s vydáváním či psaním knih, ale často jsou na besedy a autorská čtení zváni žánroví autoři, na conech se setkávají zájemci o fantastiku s těmi, kteří fantastickou literaturu tvoři - jde tedy o jeden z podstatných elementů, jimiž vzniká, je udržován a bývá rozšiřován fandom.

Všechny tyto aspekty ovlivňují poptávku fanoušků (která se kromě prodejnosti projevuje například v rubrikách časopisu XB-1 Čtenáři doporučují a Čtenáři varují) a odrážejí se v požadavcích nakladatelů - a ty se zase odrážejí v tom, co je přijato do edičního plánu a jaké texty jsou požadovány po spisovatelích. Občasné experimenty (Straky na vrbě např́klad vydaly dvojjazyčný román Sierry Dawn Písně větru, vyšlo také několik svazků „fantastické poezie“ v edici Rozstoklatý vraniklec) se mohou setkat i s dobrým přijetím u žánrové kritické obce, ale prodejnost experimentálního titulu je obvykle problematická. ${ }^{6}$

6) Sám nakladatel považoval vydání románu Písně větru za natolik riskantní podnik, že se rozhodl pro nadstandardní propagaci. Více BRONEC 2012. 


\section{Fantastično jako prostředek vyjádření v české fantastické literatuře po roce 1989}

Shrnující práce, která by zkoumala fantastický prvek v titulech mimo fandom a oblast „populární fantastiky“, v českém prostředí neexistuje. Výjimečně se objevují studie o fantastičnu v dílech konkrétních autorů (např. nevydaná disertační práce Terezy Dědinové Fantastické světy v prozaickém díle Jáchyma Topola).

Fantastické motivy prostupují zdánlivě mimetickou ${ }^{7}$ literaturu i v české literatuře (lze jmenovat např. díla Jakuba Arbesa nebo Jana Weisse). V době „obnovení chaosu v české literatuře "8 se pak př́itomností fantastických motivů vyznačuje zejména literatura označovaná jako postmoderní - díla Jiřího Kratochvila (román Medvědí román, Uprostřed nocí zpěv, povídková sbírka Má lásko, postmoderno a další), Michala Ajvaze (krátké povídky Návrat starého varana, povídkový diptych Tyrkysový orel, román Druhé město a další), Jáchyma Topola (romány Sestra, Anděl a další), Jana Křesadla (romány Fuga Trium, Obětina a další), Daniely Hodrové (zejména trilogie Trýznivé město - Podobojí, Kukly a Théta, ačkoliv psáno částečně již před rokem 1989), Petra Rákose (romány Korvína čili Kniha o havranech a Askiburgion čili Kniha lidiček), ale i Josefa Škvoreckého („nalezený rukopis“v románu Nevysvětlitelný príběh aneb Vyprávění Questa Firma Sicula) rámují mozaiku využití fantastického motivu v odbornou veřejností recipované literatuře 90 . let.

Po přelomu tisíciletí existuje množství děl s fantastickým prvkem, která byla obcí odborníků oceněna - cenu Magnesia Litera dostaly romány Hastrman Miloše Urbana (psáno s vědomím faktu, že v Urbanově díle obvykle nějaký fantastický nebo alespoň mystifikační prvek existuje - srov. např́klad romány Poslední tečka za Rukopisy, Sedmikostelí a další), Lucemburská zahrada Michala Ajvaze a Mlýn na mumie Petra Stančíka.

Stále častěji se objevují díla autorů oceňovaných za mimetickou literaturu, která obsahují fantastický prvek. V románu Chyba Marka Šindelky je to japonská upírská rostlina, která čerpá živiny z živých organismů, pokud možno z lidí, v díle Petry Hůlové se projevují tendence hodnotit dnešní společnost na základě neexistujících míst a společenství (město Krakov a paralelní dějiny

\footnotetext{
7) Pojem „mimetická literatura“ je v práci užíván pro zdůraznění skutečnosti, že jde o literaturu, která napodobuje konsenzuální realitu. Fantastická literatura je potom opakem mimetické literatury; pokud nějaký, byt̉ minimální prvek záměrně porušuje pravidla konsenzuální reality, spadá do oblasti fantastické literatury.

8) Termín Jiřího Kratochvila pro dobu krátce po roce 1989.
} 
Československa, respektive České republiky v románu Strážci občanského dobra, nověji pak dystopická feministická budoucnost v románu Stručné dějiny Hnutí), Emil Hakl používá postavu umělé ženy Umy v románu Umina verze, Bohuslav Vaněk-Úvalský postavu dvouhlavého Piolina v knize Brambora byla pomeranč mého dětství, zdánlivě mimetický román Michala Přibáně Všechno je jenom dvakrát od počátku počítá s fantastickým prvkem, kdy postavy v závěru knihy cestují v čase, a podobně.

\section{Jak najít fantastickou literaturu}

Otázka po tom, co ještě je fantastická literatura a co už není, je na tomto místě navýsost relevantní. Pro okruh vlastního fantastična existuje v českém prostředí několik soupisů knih. Od roku 1995 vzniká každý rok tzv. „přehled produkce ${ }^{\text {“9 }}$ pro potřeby členů Akademie science fiction, fantasy a hororu (ASFFH), kteří na základě těchto přehledů hlasují o Cenách ASFFH. Každé číslo Ikarie, potažmo XB-1 obsahuje na konci výčet knih s fantastickým prvkem vydaných v daném měsíci. A v roce 2005 vznikla databáze Legie.info (https://www.legie. info/), která dlouhodobě rozšiřuje a aktualizuje seznam fantastických titulů. Všechny tyto seznamy jsou ovšem ovlivněné kulturou fandomu - a tituly mimo okruh vlastního fantastična $v$ nich někdy nenajdeme.

Tak budeme v databázi Legie.info marně hledat Stručné dějiny Hnutí Petry Hůlové, Uminu verzi Emila Hakla (ale v „přehledu produkce“ za rok 2016 je tato kniha přítomna) nebo román Brambora byla pomeranč mého dětství Bohuslava Vaňka-Úvalského (ten není ani v „přehledu produkce“ za rok 2001). Tamtéž naopak nalezneme Nevysvětlitelný př́běh aneb Vyprávění Questa Firma Sicula Josefa Škvoreckého (v „přehledu produkce“ za rok 1998 tuto knihu nenajdeme) nebo Strážce občanského dobra Petry Hůlové (abychom byli důslední - v „přehledu produkce" za rok 2010 tato kniha přítomna je). Jak vidno, spoléhat na tyto databáze (přestože Legie.info je neustále aktualizována ${ }^{10}$ ) nelze. Jiné soupisy fantastické literatury ale neexistují.

Tereza Dědinová navrhuje definovat fantastickou literaturu intuitivní metodou (DĚDINOVÁ 2015: 56-59) na základě Wittgensteinovy sítě rodových

9) Seznam všech „přehledů produkce“ zde: http://www.asffh.info/prehledy-produkce.html, případně na stránkách časopisu Interkom: http://interkom.vecnost.cz/ (soubory ve formátu pdf označené zkratkou ASFFH).

10) Hovoříme o stavu databáze v květnu 2018, je možné, že zmíněné tituly budou do databáze postupem času přidány. 
podobností. ${ }^{11}$ Použijeme-li tuto metodu na výše jmenovaná díla, zjistíme, že všechna lze do fantastické literatury zařadit. Není možné projít všechny knihy vydané po roce $1989 .{ }^{12}$ Pokud bychom chtěli zkoumat dějiny české fantastické literatury nebo rozřadit texty na základě jejich př́slušnosti $k$ fantastické literatuře, je nutné spoléhat na čtenářskou zkušenost a erudici člověka, který o vybraných problémech české fantastické literatury píše.

\section{Mezi fantastickou a mimetickou literaturou}

\subsection{NÁČRT SITUACE VE SVĚTĚ}

Zvýšený zájem o fantastickou literaturu je na vzestupu od přelomu tisíciletíli $^{13}$ a způsobily jej úspěchy dvou děl náležících do neostré množiny vlastního fantastična. Jednak jde o filmovou adaptaci trilogie Johna Ronalda Reuela Tolkiena Pán prstenů, jednak o úspěch sedmidílné ságy Harry Potter. Ve světové literatuře existuje podobný trend jako v literatuře české: čím dál výraznější prostupnost a stírání hranic mezi autory fantastické a mimetické literatury. $\mathrm{Z}$ oceněných světových autorů posledních let lze zmínit např. Michaela Chabona, který za román Úžasná dobrodružství Kavaliera \& Claye ${ }^{14}$ získal roku 2001 Pulitzerovu cenu (k fantastice a detektivnímu žánru směřují i jeho další díla, např. Židovský policejní klub odehrávající se v alternativní realitě, v níž vznikl židovský stát na Aljašce, nebo novela Konečně řešení, do níž si vypůjčil postavu Sherlocka Holmese), nebo laureáta Nobelovy ceny za literaturu Kazua Ishigura, který publikoval vedle mimetických románů i Neopouštěj mě, sci-fi z budoucnosti, v níž jsou klony, nijak neodlišitelné od běžných lidí, „chovány“ na orgány, a v loňském roce román Pohřbený obr, ${ }^{15}$ mytický př́iběh z Anglie za časů bezvládí po smrti krále Artuše.

11) Konkrétněji: „Za fantastická budu tedy považovat taková beletristická či dramatická díla, v nichž fantastický prvek - propojen sítí rodových podobností s alespoň jedním dalším dílem pokládaným za fantastické - zaujímá význačnou roli ve struktuře fikčního světa, neobjevuje se pouze ojediněle nesa zcela specifickou funkci“ (DĚDINOVÁ 2015: 59).

12) Dle databáze Legie.info bylo od roku 1989 do konce roku 2012 publikováno více než 1100 knih z oblasti fantastické literatury. A jak je uvedeno výše, ani v této databázi nejsou všechny relevantní tituly uvedeny.

13) Viz např. ankety New York Times a BBC.

14) Román, jehož děj začíná v Praze a který lze číst jako historii vzestupu komiksové kultury, obsahuje množství fantastických motivů. Mimo jiné je v něm pašován pražský golem.

15) Kazuo Ishiguro pochyboval, zda budou jeho nový román fanoušci číst, protože by si mohli říci, že „to je přece fantasy“. Dočkal se ostré reakce od Ursuly K. Le Guinové. Více viz ALTER 2015 a LE GUIN 2015. 


\subsection{NÁČRT SITUACE V ČESKÉ REPUBLICE}

V českém prostředí lze průniky sledovat obdobně. Petra Stančík, jehož Mlýn na mumie získal cenu Magnesia Litera a byl hodnocen převážně v nežánrových médiích, v roce 2004 přispěl do časopisu Ikarie povídkou Drakodav a v roce 2017 se jeho povídka Ahaswehrmacht stala součástí žánrové antologie Ve stínu Řiše. Druhým takovým autorem je René Vaněk. Po debutu Nezahrada a novele Soma secundarium se jeho povídka Digimengele objevila také v antologii Ve stínu Řiše. Autorem s opačným směřováním je Jan Poláček. Po povídkách v subžánru kyberpunk a fantasy románu ${ }^{16}$ (povídky Ex Machina vyšly roku 1991, román $V$ těch temných dobách v roce 1994, obojí pak v žánrovém nakladatelství Winston Smith) napsal psychologický román Spánek rozumu plodí nestvưry (2000), za který obdržel Cenu Knižního klubu, pak se vrátil ke kyberpunkovým povídkám (Kyberpunk \& Heavy z roku 2006), pokračoval dystopickým románem z alternativní minulosti Spěšný vlak Ch.24.12 (2010) a v poslední době se zabývá životopisnými texty (osobnosti Ladislava Fukse je věnován Příběh spalovače mrtvol, 2013, „pražskému mágovi“ Jiřímu Arvédu Smíchovskému pak Malostranský d’ábel, 2016) a tvorbou pro děti (příběhy o detektivu Matyldovi).

\section{Hodnocení na základě intratextuálních znaků}

Druhým možným hlediskem, náročnějším pro recipienta, je sledovat průniky mezi fantastickou a mimetickou literaturou na základě vnitřní analýzy. Pokusíme se o to analýzou dvou povídkových sbírek Jana Dobiáše a novely Soma secundarium Reného Vaňka.

\subsection{PovídKy JANA DoBIÁŠE}

Jan Dobiáš ( $\left.{ }^{*} 1975\right)$ publikoval dvě sbírky fantastických povídek v žánrovém nakladatelství Straky na vrbě, Po dračím ohni (2006) a Neočekávané dýchánky (2016). Po dračím ohni se skládá z 23 povídek, Neočekávané dýchánky z 15 povídek. Není možné zde analyzovat všechny (kvalitativně se také odlišují), vybereme $\mathrm{z}$ každé sbírky dvě pro naše účely nejzajímavější povídky.

16) Sám autor o knize mluví jako o „kyber-fantasy“ (HOKR 2013). 
Většina Dobiášových povídek je typická třemi prvky - zasazením typických fantastických motivů do současného světa, aluzemi na známá díla žánrové i jiné literatury a humorem, který vzniká často na základě předchozích dvou prvků.

Povídka Měsíc v drakmarktu popisuje zkušenosti zaměstnance supermarketu řízeného drakem a obsluhovaného fantastickými bytostmi. Primární funkce textu je zábavná a z paralel mezi realitou povídky a realitou naší plynou překvapivě aktuální skutečnosti. Supermarket je postaven během velmi krátké doby, ${ }^{17}$ základními rysy jsou všudypřítomná konzumní společnost, ${ }^{18}$ nutná administrativa i snaha „vytěžit lidské zdroje“. ${ }^{19}$

Povídka Tajná apokalypsa nese další prvek typický pro fantasy - boj dobra a zla. Čtenář sleduje příběh archanděla Michaela, který společně s dalšími, kteří zbyli, ${ }^{20}$ vyráží do poslední bitvy proti armádám démonů. Na setkání posledních přeživších přijíždí vlakem, do hotelu, kde bydlí, jedou taxíkem. Povídka je tragická - akcentuje samotu, konkrétně samotu ve víře: „Vzduch sršel energií. Gabriel smutně vzhlédl do bezedné černi noční oblohy. ,Myslíte, že se dívá?' Dobrá otázka. Dřív bych to poznal. A potom čím dál méně a méně, až se mi vytratil docela. Opustila mě ta schopnost, nebo on sám?“ (DOBIÁŠ 2006: 261). Andělé zvítězí, ačkoliv všichni padnou. Zraněný Michael na konci uslyší zvon a z posledních sil vyrazí do kostela: „Dům boží. Zkroucený křečí jsem dovrávoral k jeho vratům a opřel se do nich. Zavřeno. Sebral jsem všechny síly, co mi jich jen zbylo, a zabral. Praskot lámané závory, skř́ípění zarezlých pantů. Je po všem. Vracím se domů. Obě těžká křídla se pomalu rozevřela a já zůstal stát nad bezednou hlubinou. Uvnitř kostela nebylo nic než prázdnota“" (DOBIÁŠ 2006: 265). Poslední věta povídky je dvojsmyslná prázdnota je jednak reálná (tj. v kostele nic a nikdo není), jednak metafyzická, odhaluje konec nadějí, odráží prázdnotu protagonisty.

Povídkou Neočekávaný dýchánek sbírka z roku 2016 začíná. Aluze na první kapitolu Tolkienova Hobita je zřejmá - Dobiáš příběh takřka opisuje. Na chatu kousek za městem přijíždí protagonista, aby místo připravil (chystá se

17) „Nový dračí supermarket vyrostl v místě někdejší gobliní tržnice za městem díky Pekelné stavebni s. r. o. během jediné noci. Následujícího rána visely na všech rozích vylepené plakáty s nabídkou perspektivního zaměstnání za dobrý plat" (DOBIÁŠ 2006: 130).

18) „Daleko vzadu se proti pošmourné prosincové obloze rýsovaly holé pahýly kouzelného lesa, kde údajně dosud bloudí stíny dávných bohů a démonů, pohrdajících novými médii, moderním marketingem i reklamou, a tudíž odsouzených k nevyhnutelnému zániku a zapomnění" (DOBIÁŠ 2006: 130-131).

19) „ZZačnete tedy hned!‘ To hned znamenalo, že zbytek dne zabere papírování /dračí záliba v lejstrech je pověstná, podle některých právě cupaninou z úředních akt každé ráno znovu oživují svůj žár, úplně stejně, jako když roztápíte stará kamínka na dřevo/ a potom, hned po zavírací hodině, nastoupím na noční směnu. Doplňování regálü“ (DOBIÁŠ 2006: 133).

20) „Zvrátil jsem hlavu k nebi, napůl v naději, že se otevře a andělská jízda vyjede s hlaholem polnice do útoku. Nic takového se samozřejmě nestalo. Žádná andělská jízda už není. Andělé vymřeli“ (DOBIÁŠ 2006: 264). 
„kalba“, ale Lukáš, se kterým protagonista na začátku hovoří, nemá čas, proto prosí o pomoc s přípravou chaty). Je upozorněn, že se v okolí hraje LARP ${ }^{21}$ a že možná někdo přijde na návštěvu. Skutečně se na chatě sejdou trpaslíci s povědomými jmény jako Dvalin, Kili, Fili, Bofur a Bombur. Tato aluze je důrazně přiznaná, je třeba, aby čtenář Hobita znal, ale právě v napětí mezi pretextem a textem vzniká aktualizace tématu. Očekávaný čaroděj nakonec nedorazí, takže trpaslíci nad ránem opět vyrážejí na cestu. A tehdy se v protagonistovi odehraje až joyceovské prozření: „A jak je tak vyprovázím pohledem, najednou na mě padl takový divný smutek. Jako bych sahal po něčem, co bych si vlastně nikdy ani neodvážil přát, po něčem úžasném, vzácném, nedosažitelném, už už to držel, a vtom mi to někdo vytrhl z rukou a navždy odnesl někam daleko, někam, kde už to víckrát nenajdu." (DOBIÁŠ 2016: 21). Stejně jako Bilbo Pytlík i tento bezejmenný protagonista se za trpaslíky na poslední chvíli rozběhne, čímž povídka končí. Přenesením schématu, které použil Tolkien, do aktuální doby je ukázáno, že touha po dobrodružství, po útěku ze stereotypu zůstává i v moderním člověku - to, co platilo v Hobitovi, platí i v roce 2016 u Dobiáše. Protagonista se nediví, že k němu přijdou trpaslíci a snědí a vypijí, co mohou. Jádro jeho zájmu (a tedy i zájmu čtenáře) je v touze vymanit se $\mathrm{z}$ běžných schémat, zažít nějaký „neočekávaný dýchánek“.

Příkladem nefantastickým je povídka Zítra bude válka. Malý kluk nespecifikovaného věku touží po boji, ${ }^{22}$ rozšiří tedy zprávu o tom, že bude válka. Poplašná zvěst se roznese, za chvíli jí věří celá škola. Nic se nakonec nestane, až hlavního hrdinu o pár měsíců později vzbudí podivné otřesy. Když se podívá z okna, uvidí projíždějící tanky: „,Mami, tati!' rozfňukal se tiše s nosem u podlahy. ,Promiňte, já nechtěl! Tohle jsem vážně nechtěl!' Byl dvacátý první srpen roku osmašedesát" (DOBIÁŠ 2016: 224).

Dobiášovy povídkové sbírky nesou typické znaky příslušnosti $\mathrm{k}$ neostré množině vlastního fantastična. Byly vydány v žánrovém nakladatelství, obsahují prvky náležící nejčastěji k fantasy, grafická úprava signalizuje zjevné žánrové zasazení. Obsahem ale povídky zobrazují současné problémy, vnitřně k neostré množině vlastního fantastična náleží jen okrajově - mnohem více by odpovídalo jejich zařazení do neostré množiny fantastična jako prostředku vyjádření. Měsíc v drakmarktu kritizuje současnou konzumní společnost

21) LARP - z anglického „live action role playing“, živá „hra na hrdiny“.

22) „Kdyby se tak něco stalo, říkal si. Cokoli. Přijít na svět o pár století dřív, mohl být husitským práčetem a místo psaní domácích úkolů bít po hlavách zlotřilé křižáky. Stihnout to jen o pár let, zažil by ještě druhou světovou, utekl k partyzánům a bojoval s fašisty. Jenže on je prostě smolař“ (DOBIÁŠ 2016: 221). V tom se ostatně povídka tematicky shoduje s předchozí komentovanou povídkou. 
a podmínky zaměstnanců obchodních řetězců, Tajná apokalypsa zkoumá vztah Boha a člověka (respektive anděla, kterého ovšem vnímáme jako bytost člověku velmi podobnou), Neočekávaný dýchánek vyjadřuje odvěkou touhu po dobrodružství, po jiném, lepším životě; a Zítra bude válka je povídkou, kde lze fantastický prvek spatřit snad pouze $v$ tom, že chlapec nechtěně předpověděl budoucnost a že je nepravděpodobné, aby na základě jeho tvrzení uvěřilo zmíněné poplašné zprávě celé jeho okolí - tuto poslední povídku lze přiřadit $\mathrm{k}$ mimetické literatuře, přestože všechny extratextuální znaky odkazují k množině vlastního fanastična.

\subsection{SOMA SECUNDARIUM RENÉHO VAŇKA}

Novela je zasazena do zcela konkrétního časového rámce: „,Ty, Kocoure! Pojd’ napsat na tabuli dnešní datum.' Přikývl jsem, vstal od psacího pultíku a došel k tabuli, kde mi Fanatikova ruka, připomínající nohatého pavouka, podala kus křídy. Napsal jsem na tabuli: 14. srpna 1982“ (VANĚK 2011: 8-9). Propriety, které používá, patří $\mathrm{k}$ běžným atributům dané doby a běžné tehdejší reality: školní docházka, obchod se smíšeným zbožím, v prosinci návštěva Mikuláše, popeláři, časopis Čtyřlístek. Ale vše popsané je pokřivené, groteskně znetvořené, absurdní. Hlavní hrdina Kocourek má bratra Ernesta, který žije v Kocourkově břiše ${ }^{23}$ obchod se smíšeným zbožím je popsán jako děsivé místo, kterému vládne strašlivý Prodavač a jehož chladící box obsahuje mimo jiné neméně děsivé kňourající kojence, ${ }^{24}$ Mikuláš je příšernou kreaturou s tlamou lemovanou kruhem ohromných zubů a podobně. Celá novela je tvořena vyprávěním Kocourka, který je na místě, kde existuje pouze Tma a kde mu zůstaly pouze

23) „Ernest byl moje vnitřní siamské dvojče. Roztomilé malé skřítě, dřímající mezi kličkami mého tenkého střeva. Byl živ tím, co jsem pozřel a vypil, mé plíce za něj dýchaly, v mých ledvinách se tvořila jeho moč. Jeho život byl v mých rukách, a i kdybych býval stokrát chtěl, nešlo na tom změnit absolutně nic" (VANĚK 2011: 15). Srov. s románem Bohuslava Vaňka-Úvalského Brambora byla pomeranč mého dětství, ve kterém má hlavní hrdina dvě hlavy: „To, že Piolin měl dvě hlavy, bylo pro něj sice nepř́ijemné, ale když chce člověk žít, je prvním předpokladem zvyknout si. Naše máma vždycky ř́ikala: ,Zvykni si na to, že si lidé vždycky rychle zvyknou. Když něčemu nepřivyknou, zmiz odtamtud, protože něco je v nepořádku.' Podle všeho je prvotní smysl života zakódován ve slově zvyk. Teprve po něm následuje slovo smíření. Taky jsem mohl dopadnout hůř, než být spojen s tělem, jež mi nepatřilo. Když šel někdy Piolin pozdě do školy, stavili jsme se na kus řeči u pomníčku neznámého bojovníka. Na rozdíl od nás měl jenom jednu hlavu a nedožil se ani dvacíti“ (VANĚK-ÚVALSKÝ 2001: 36).

24) „Zatnul jsem zuby a nahlédnul do útrob boxu. U dna se mezi vším možným plazili tiše kňourající kojenci, pokrytí vrstvičkou jinovatky. Jejich buclaté prstíky neohrabaně dorážely na uzávěry lahví s mlékem. Měli obrovský hlad. Někteři z nich byli k láhvím přimrzlí rty, žalostně kňourali a marně se pokoušeli odtrhnout. Chvíli jsem v oněmění sledoval tu srdceryvnou scénu a bojoval s vlastní měkkou povahou. Kdybych neodolal, jednu z lahví otevřel a nemluvňata by se napila, stalo by se něco strašného. Tuhle chybu jednou udělala Klára. Od té doby chvílemi koktala a velikým obloukem se v kuchyni vyhýbala ledničce" (VANĚK 2011: 21). 
vzpomínky. Ty vypráví čtenáři. Popsaný svět je fascinující, bizarní, originální a velmi svébytný. Vaněk pracuje s repertoárem zcela obyčejných skutečností, kterým přisuzuje groteskní a často makabrózní charakter, aniž by kladl důraz na logiku příběhu či konzistenci fikčního světa. Tímto odcizením je předkládaný svět ještě nepříjemnější, nepřátelštější.

(1) Fantastičnost knihy spočívá ve třech aspektech. Prvním jsou skutečnosti odlišné od konsenzuální reality - kojenci v mrazáku, postava bratra žijící v břiše protagonisty a podobně. Druhým aspektem je „zcizenost“: fakt, že obyčejné prvky z běžného života nesouzní s tím, na co jsme zvyklí. Patří k tomu i historická skutečnost života v roce 1982 („Utíkal jsem městem, kterému možná vládl sluneční svit, ale na každém jeho nároží leželo něco mrtvého, obaleného bzučícím hmyzem. Běžel jsem světem rozkladu“ VANĚK 2011: 154), ale převažují situace, které lze demonstrovat na následujícím úryvku: „Takový můj pomyslný budík byla nepočetná tlupa popelářů, sídlících v jedné ze sklepních kójí protějšího domu. Každý den, přesně za pět minut šest, se všichni vyštrachali sklepním okénkem do ulice, vrhli se mlsně na popelnice, překotili je na zem a začali dravě hodovat na tom, co bylo prohlášeno za nepotřebné a štítivě upuštěno do smetí (VANĚK 2011: 16). Jak je vidět, z běžného zaměstnání (popelář) je vytvořeno něco groteskního, absurdního - tlupa tvorů či osob, která sídlí ve sklepě protějšího domu a která skutečně funguje jako „reální“ popeláři: vyklízí popelnice. S tím souvisí i třetí aspekt: nelogičnost. Ve Vaňkově apokalyptickém světě nedostatku prostředků i lidí není logicky možné, aby byly popelnice naplněny. Vaňkovi popeláři by brzy zemřeli hlady. Nelogičnost jednotlivých prvků světa ovšem přispívá $\mathrm{k}$ fantastičnosti knihy - podobným způsobem, jako jsou fantastické (nereálné) schody z Escherových obrazů.

Kniha Soma secundarium by mohla vyjít v žánrovém nakladatelství. Lišila by se od běžné produkce, ale žánrová kritická obec by ji patrně vzala na vědomí. Takto vyšla v žánrových médiích pouze jediná recenze ${ }^{25}$ zatímco v nežánrových médiích se dočkala recepce v recenzích Evy Klíčové a Pavla Janouška v Hostu a Tvaru. Recenze Evy Klíčové je negativní, ale zároveň vykazuje znaky nepochopení textu: „Už první stránková kapitola - krkolomně líčící vnímání světa uvnitř bratrova těla uvězněného Ernesta (zřejmě tedy), který předesílá, že bude vypravěčem, jímž je ale následně Kocourek - odhaluje, že Vaněk čtenáře pěkně potrápí“ (KLÍČOVÁ 2012). První stránková kapitola je vyprávěná Kocourkem (je nazvána Konec, zjevně tedy odkazuje ke konci knihy, kde Kocourek končí 
ve Tmě), Ernest se ukáže být zápornou postavou, ale v žádném okamžiku knihy není vypravěčem. Eva Klíčová si správně všímá podivného časového rámce („Co ale zároveň mate, je explicitní vročení do let 1982-1983. Že by šlo o jakousi paranoickou pseudovzpomínku /viz autorův věk/ na socialistickou éru?") a motivů traumat z dětství („[...] jít sám nakoupit, říct básničku Mikuláši, zklamání pod vánočním stromečkem, návštěva holičství nebo evergreeny v podobě frustrující konzumace čehokoliv z donucení.“ - obě citace KLÍČOVÁ 2012). Pavel Janoušek zdơrazňuje vazbu na tradiční žánry blízké fantastice, když podotýká, že Vaněk využivá „žánrových postupů, jež geneticky odkazují ke sci-fi, hororu, pohádce i tradiční romantické novele s tajemstvím. [...] avšak svět, který tu líčí, je zcela jiný svět, než je ten náš - je variací na postapokalyptické vize známé především z béčkových filmů“ (JANOUŠEK 2012). I Pavel Janoušek považuje dílo za nedotažené, ${ }^{26}$ ale vyzdvihuje Vaňkův zjevný talent.

Vaňkova novela nese extratextuální znaky příslušnosti k mimetické literatuře, ovšem vnitřně náleží do neostré množiny fantastična jako prostředku vyjádření. Přes nezvládnutou strukturu (dle citovaných recenzí) naznačuje fikční svět knihy přesah ke konsenzuální realitě - pro čtenáře je ale tento přesah obtížně srozumitelný. Fantastický prvek je klíčový pro estetický dojem z knihy (protože za normálních okolností nejsou obchod se smíšeným zbožím, nemluvňata nebo Mikuláš hrozbou), ale zároveň jej lze brát jako kulisu, prostředek k vyvolání šoku ve čtenáři.

\section{Závěr}

Od dob prvního výraznějšího odborného uchopení české fantastické literatury, a to zejména fandomové, v první polovině 90. let 20. století (Slovník české literární fantasiky a science fiction, Encyklopedie literatury science fiction a Langerova studie Prưvodce paralelními světy) ${ }^{27}$ nedošlo k zevrubnější recepci tohoto žánru/modu (pomíjíme práce Antonína Kudláče, které se týkají vybraných

26) „Závěry próz, jako je ta Vaňkova, se ovšem možnosti jejich jednoznačného kauzálního vysvětlení značně vzpírají, a to mimo jiné proto, že takové vysvětlení nezná ani sám jejich autor. Toho totiž jeho hrátky s fantazií přivedly až do bodu, ve kterém mu už nezbylo než ještě jednou zašvindlovat s mnohoznačnými náznaky a metaforickými neurčitostmi. Cílem bylo navodit ve čtenáři pocit úplně tajemného tajemství a tím na něj přenést odpovědnost za vyznění textu. Postavit jej do situace, kdy má domyslet nedomyšlené a nedomyslitelné a ještě být nadšen, že mu to autor umožnil“" (JANOUŠEK 2012).

27) Přestože přepracované vydání vyšlo roku 2006, jádro práce shrnuje vývoj fantastické literatury do roku 1993. 
dílčích jevů). Prvním problémem je vůbec definice toho, co fanastická literatura je. Druhým problémem, kterým se zabývala tato studie, je dvojdomost fantastické literatury. Nelze ji prostě pominout jako nepodstatnou - tvoří podstatnou část žánrového povědomí, ${ }^{28}$ ale potvrdit ji na základě analýzy pouhých dvou textů také není možné. Tato studie ovšem konkretizuje neostrost dvojdomosti české fantastiky - pokud bychom $\mathrm{k}$ této problematice přistupovali mechanicky, nutně bychom dospěli k chybným závěrům.

Shodneme-li se na tom, že by bylo vhodné vytvořit nové, aktuální dějiny české fantastické literatury, bude třeba se s tímto jevem vypořádat. Nelze pouze definovat „populární fantastiku“ (ač nepochybně existuje) a zařadit do ní knihy př́slušných nakladatelství, které budou recenzovány v konkrétních médiích a které budou prodávány ve specializovaných knihkupectvích - učiníme-li tak, budou výsledky nepřesné a zkreslující.

Také není možné absorbovat veškerou produkci české fantastické literatury. Možností náročnou, ale dle mého názoru jedinou je spolehnout se na čtenářskou zkušenost badatele a zaměřit se nikoliv na žánrová kritéria, ale na specifika využití fantastického prvku.

\section{PrAMENY}

DOBIÁŠ, Jan 2016 Neočekávané dýchánky (Praha: Straky na vrbě) 2006 Po dračím ohni (Praha: Straky na vrbě)

VANĚK, René

2011 Soma secundarium (Praha: Mezera)

VANĚK-ÚVALSKÝ, Bohuslav

2001 Brambora byla pomeranč mého dětství (Brno: Petrov)

\section{LITERATURA}

DĚDINOVÁ, Tereza

2015 Po divné krajině (Brno: Masarykova univerzita)

28) „Žánr je instituce geneticko-recepční, tj. týká se vzniku i vnímání textu - tedy celé oblasti života literárního díla“ (ŠIDÁK 2013: 66). 
JANOUŠEK, Pavel a kol.

2008 in Dějiny české literatury 1945-1989. IV. díl (Praha: Academia)

JANOUŠEK, Pavel

2012 „969 slov o próze. René Vaněk: Soma secundarium, Mezera, Praha 2011“, Tvar 23, č. 3, s. 3

KLÍČOVÁ, Eva

2012 „Když internet vyvrhne prozaika“, Host, 28, č. 5, s. 68

KUDLÁČ, Antonín K. K.

2016 Anatomie pocitu úžasu. Česká populární fantastika 1990-2012 v kulturním, sociálním a literárním kontextu (Brno: Host)

MACEK, Jakub

2006 Fandom a text (Praha: Triton)

NEFF, Ondřej

1981 Něco je jinak (Praha: Albatros)

ŠIDÁK, Pavel

2013 Úvod do studia genologie: Teorie literárního žánru a žánrová krajina (Praha: Filip Tomáš - Akropolis)

\section{INTERNETOVÉ ZDROJE}

ALTER, Alexandra

2015 „For Kazuo Ishiguro, The Buried Giant is a Departure“, https://www.nytimes.com/, dostupné z: <https://www.nytimes.com/2015/02/20/books/for-kazuo-ishiguro-the-buried-giant-is-a-departure. html?_r=1>, přístup 12. 6. 2018

BRONEC, Michael

2012 „Songy větru (PR)“, http://www.fantasyplanet.cz, dostupné z:

<http://www.fantasyplanet.cz/uncategorized/songy-vetru-pr/>, př́stup 12. 6. 2018

DAGON - Strážce bran fantastiky

2018 [Čas od času některé věci zkrátka končí (alespoň částečně)...], in Facebook, 8. 4. 2018, dostupné z: <https://www.facebook.com/www.dagon.cz/>, př́stup 12. 6. 2018

HOKR, Boris

2013 „Rozhovor s Janem Poláčkem, autorem Př́běhu spalovače mrtvol“, http://interkom.vecnost.cz, dostupné z: 〈http://interkom.vecnost.cz/pdf/ik201309cl.pdf〉, přístup 12. 6. 2018

JIREŠ, Ondřej

2004 „FP je tu čtyři roky!“, http://www.fantasyplanet.cz, dostupné z: <http://www.fantasyplanet.cz/uncategorized/fp-je-tu-ctyri-roky/>, př́stup 12. 6. 2018 


\section{KŘEČEK, Jan}

2012 „Soma secundarium - trochu jiná kniha“, http://www.sarden.cz, dostupné z:

<http://www.sarden.cz/2012-04-08-1952/recenze-soma-secundarium-trochu-jina-kniha〉, př́stup 12. 6. 2018

\section{LE GUIN, Ursula K.} 2015 „Are they going to say this is fantasy?“, http://bookviewcafe.com. dostupné z:

<http://bookviewcafe.com/blog/2015/03/02/are-they-going-to-say-this-is-fantasy/>, prístup 12. 6. 2018

\section{RAMPAS, Zdeněk}

2000 „Hvězdný bulvár“, http://interkom.vecnost.cz, dostupné z:

<http://interkom.vecnost.cz/2000/20000504.htm〉, př́stup 12. 6. 2018

\section{DALŠÍ ZDROJE}

\section{HARTMAN, Ondřej}

2018 rozhovor 15. 6. 2018, Facebook

Při vzniku práce byly využity zdroje výzkumné infrastruktury Česká literární bibliografie (http://clb.ucl.cas.cz) a Legie - databáze knih Fantasy a Sci-Fi (https://www.legie.info/).

Mgr. Jan Křeček, jan.krecek@email.cz, Ústav české literatury a knihovnictví, Filozofická fakulta, Masarykova univerzita, Brno, Česká republika / Department of Czech Literature and Library Studies, Faculty of Arts, Masaryk University, Brno, Czech Republic 